\title{
Experimental Study on the Smouldering Combustion of Mineral Wool Insulation in Chimney Penetrations
}

\author{
Perttu Leppänen, and Mikko Malaska* (D), Civil Engineering, Tampere \\ University, P.O. Box 600, 33014 Tampere, Finland
}

Received: 13 June 2018/Accepted: 22 March 2019

\begin{abstract}
A large number of fires have been caused by metal chimney penetrations in recent years. One factor that has contributed to these occurrences is smouldering combustion within mineral wool, which is often used as insulation in metal chimneys and their penetrations. Based on reaction to fire performance mineral wool is typically classified as a non-combustible material and in European standards it belongs to category Euroclass A1. However, mineral wool insulation products contain organic material, which smoulders and generates heat at temperatures between $200^{\circ} \mathrm{C}$ and $500^{\circ} \mathrm{C}$. Experimental research indicates that this additional heat may increase the temperature in the chimney penetration materials over $100^{\circ} \mathrm{C}$ for a limited period of time. The European fire classification of materials does not set requirements to control mineral wool smouldering and limit the subsequent heat release. This experimental study examined the smouldering of mineral wool insulation products specified for chimney penetrations and the heat release generated during the smouldering combustion. The aim of the study was to determine the actual level of temperature increase within the chimney penetration and to estimate the effects of the increase with regard to fire safety. The study also reviewed how the smouldering potential of an insulation material could be considered in the fire classification of products.
\end{abstract}

Keywords: Smouldering combustion, Mineral wool, Chimney, Fire safety, Heat release

\section{Introduction}

Despite mandatory certification procedures, some European countries have reported a high number of fires due to the presence of chimneys. For example, in Finland 600-700 building fires caused by fireplaces and chimneys are reported each year [1]. Similar fire safety problems have also been reported in other European countries [2]. In the United States, the majority of residential fires involved solidfuelled equipment and fires were caused by the ignition of structural frame components [3]. Figure 1 shows a picture from a roof space in which the heat of a metal chimney has led to the ignition of the surrounding roof insulation material and caused a fire. Several reasons for chimney-penetration-induced fires have been

\footnotetext{
* Correspondence should be addressed to: Mikko Malaska, E-mail: mikko.malaska@tuni.fi
} 
identified. These include, for example, the fact that the actual on-site flue gas temperatures are higher than assumed in chimney design [4, 5], faulty installations, use contrary to operating instructions [6] and the smouldering combustion of mineral wool insulation [6-8]. Previous research by Neri et al. [9-11] and Leppänen et al. $[4,5,12]$ have also shown that the standard test set-up and conditions are often different from the actual site installations and may not always lead to a safe solution. All the above issues can increase the temperatures in the roof construction.

Critical details for ensuring fire safety involve the places where chimneys pass through floors, roofs and walls. Based on the product standards of chimneys, the normal flue gas temperatures in residential use vary; for example, for metal chimney products [13], the normal working temperature can be $600^{\circ} \mathrm{C}$ in the most severe temperature class. Chimney penetration insulation and specific chimney penetration components are used to isolate the hot flue gasses from the flammable insulation materials and structural elements. The purpose of this insulation layer around the chimney is to reduce the surface temperatures adjacent to the chimney down to the level where ignition of the materials does not occur. In chimney product and test standards, the fire safe temperature level at the safe distance is set so low that there is no ignition hazard, even if the material is exposed to this temperature over a protracted period of time. In regulations, a maximum temperature of about $100^{\circ} \mathrm{C}$ has been considered safe for wood under prolonged exposure [14]. The approval of fire safety for metal chimneys is based on a CE marking and a chimney meets the requirements set in EN 1856-1 [13] if the temperature measured at a safe distance from the outer surface of the chimney does not exceed $85^{\circ} \mathrm{C}$, when tested in accordance with EN 1859 [15]. The safe distance to combustible material is specified by the manufacturer of the chimney product. Temperatures inside the area defined by the safe distance are higher and vary between the flue gas temperature and $85^{\circ} \mathrm{C}$.

Mineral wool products are often used as the insulation in chimney penetrations. According to standard EN 13501-1 [16], these products are classified as non-com-

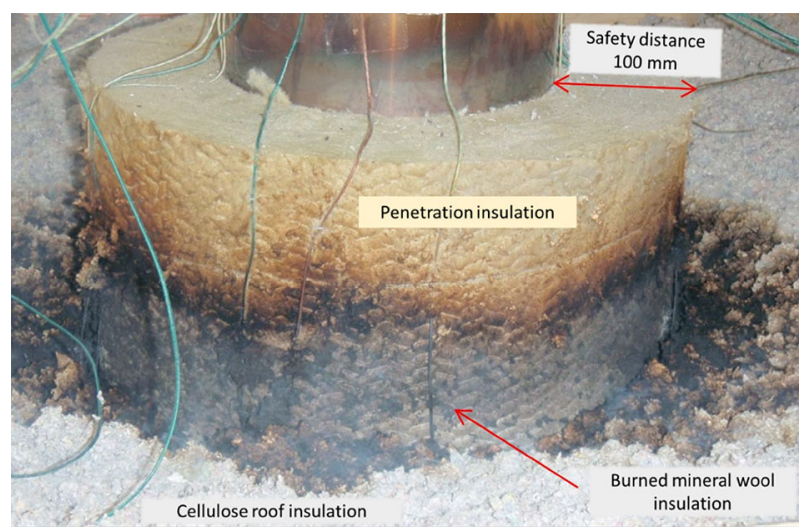

Figure 1. Chimney roof penetration after a fire. 
bustible. Mineral wool always contains binder, which is organic. In addition, other organic materials may be used for, for example, dust binding. Earlier research [6-8] have indicated that smouldering combustion of this organic material can occur in the chimney insulation. Smouldering is a flameless combustion that spreads at very low velocity in porous medium and it is characterized by heat release. The initiation of smouldering process is dominated by the oxidation of the medium and can occur when enough energy is available [17]. In case of a chimney penetration insulation, hot flue gasses supply the energy. Stable process occurs if the porous material has sufficient thickness and serves as a heat insulator to prevent heat release from the reaction to the environment [18-20]. In smouldering processes, temperatures ranging between $400^{\circ} \mathrm{C}$ and $750^{\circ} \mathrm{C}$ have been measured in the reaction area. Smouldering combustion generates additional heat in the penetration structure that, in turn, increases the temperature of both the penetration insulation and the surrounding floor and roof structures. The additional heat may have a significant effect on the temperature of chimney penetrations and create a potential fire hazard in the surrounding structures. The organic material starts to evaporate when its temperature reaches $200^{\circ} \mathrm{C}$ and, based on the research by Leppänen et al. [7], all organic material has burned off when the temperature exceeds $500^{\circ} \mathrm{C}$. Similar fire performance and pyrolysis of binders have been reported for stone wool in [21].

The amount of additional heat generated by smouldering combustion depends on the amount of organic material and the maximum temperature of the insulation. Figure 2 displays temperatures measured by Inha et al. [6] at the penetration insulation during two successive chimney tests on the same test specimen. In the test specimen, the metal chimney was connected to a sauna stove and installed through a $200-\mathrm{mm}$ thick mineral wool insulation layer. The temperatures in Fig. 2 are measured from a thermocouple that is located in the middle of the mineral wool insulation layer and $100 \mathrm{~mm}$ from the face of the chimney flue. The solid curve for Test 1 includes the additional heat release generated by the burning of the organic material. The chimney test was then repeated using the same structure, the result of which is the temperature development depicted by the dashed curve for Test 2 . The organic material burned in Test 1 , while the additional heat generation was no longer detected in the second test. The difference between the two curves can be interpreted as the additional heat generated by the burning of organic material. The maximum difference in temperature was measured at $140 \mathrm{~min}$ and it was $230^{\circ} \mathrm{C}$. After reaching its maximum value, the temperature of Test 1 started to decrease, which means that the organic content had burnt off. Temperatures in both tests were then approaching similar temperature level. The estimated duration of the temperature peak in this test was approximately $150 \mathrm{~min}$. Hereafter, the additional heat generated by the burning of organic material is the difference between the maximum values of Tests 1 and 2 .

Figure 3 shows an idealised vertical section where a chimney penetrates roof construction. The maximum continuous working flue gas temperature, which in this example is assumed to be $600^{\circ} \mathrm{C}$ in real use conditions, corresponds to temperature class T600 of EN 1856-1 [13]. The standard test temperature specified for class $\mathrm{T} 600$ is $700^{\circ} \mathrm{C}$. This is a very typical situation, for example, in Finland. In 

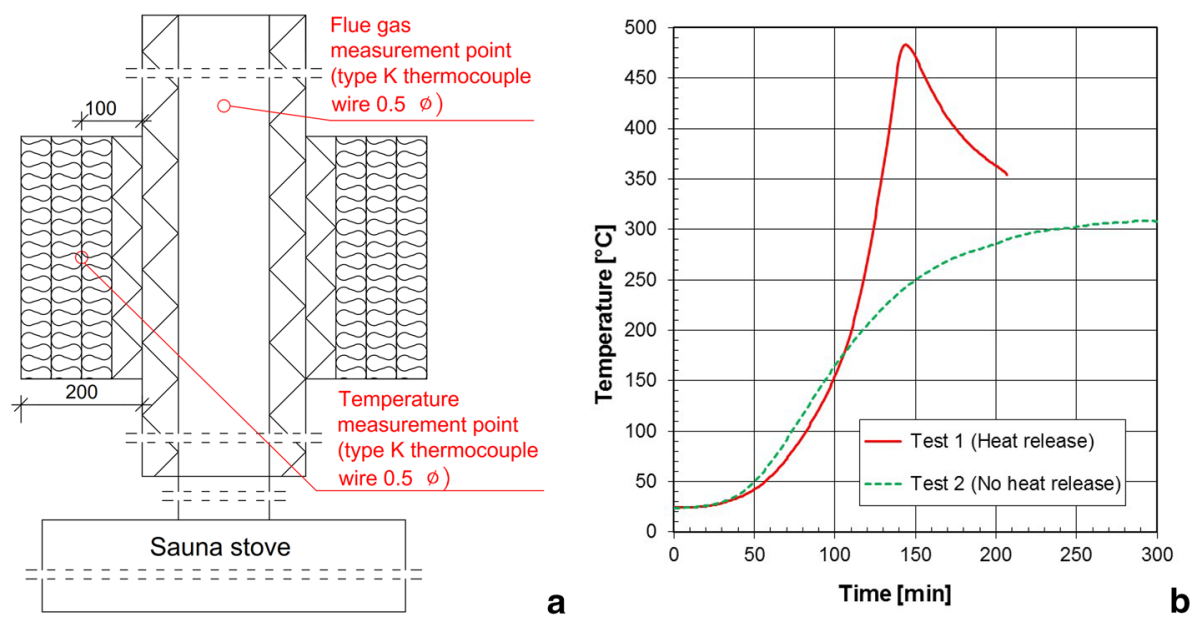

Figure 2. Temperature development measured from inside the penetration insulation during a chimney test [6]. a The cross-section of the studied chimney penetration and the temperature measurement location. b Temperature development: Tesł 1 depicts the changes in temperature, including the heat release generated by the burning of organic material. Test 2 represents a case where the insulation does not contain organic material.

this idealized example, a 100 -mm-thick penetration insulation is used around the chimney flue and the outer face of the penetration insulation defines the safe distance from the chimney flue. In actual chimney installations the insulation thickness and safety distance required are normally designed on a case-by-case bases and they depend on chimney and penetration construction as well as on properties of penetration insulation products. Roof construction, including thermal insulation and timber roof structures, are installed in contact with the penetration insulation. In the figure, the dashed blue curve represents an allowable temperature distribution where the temperatures do not exceed $85^{\circ} \mathrm{C}$ outside the safe distance of $100 \mathrm{~mm}$. A solid red curve illustrates the situation where the additional heat generated by the burning of organic material has raised the temperatures. If the temperatures outside the safe distance, area highlighted with red hatch marks in Fig. 3, exceed the ignition temperature of the roof construction materials, the fire hazard is apparent. Smouldering combustion generates heat over a relatively long period of time, which makes the problem even more serious, as the material ignition temperatures decrease when the structures are exposed to high temperatures over a longer period of time.

The building materials used for roofs are usually wood-based, mineral wool insulation and plastic insulation materials. For wood, it is not possible to determine an unequivocal ignition temperature because it is dependent on exposure time. According to Babrauskas [22], wood ignites at around $250^{\circ} \mathrm{C}$ during shortterm fire exposure. After a few hours of exposure, the ignition temperature can be 


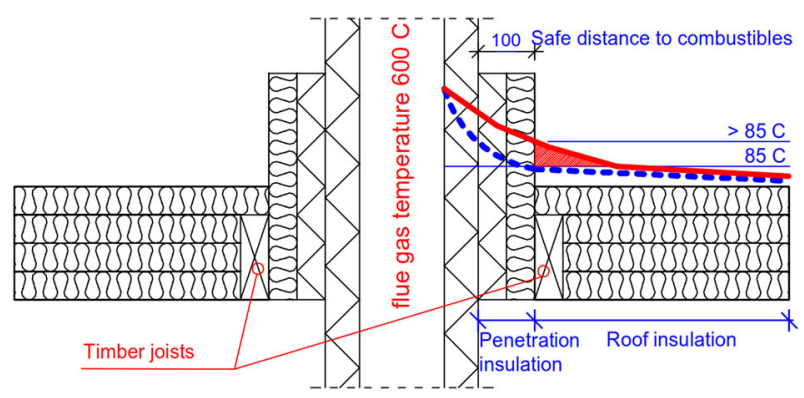

Figure 3. Idealised figure of a vertical section of a roof and the temperature distribution across the penetration structures. The dashed blue curve represents an allowable temperature distribution where the temperatures do not exceed $85^{\circ} \mathrm{C}$ outside the safe distance of $100 \mathrm{~mm}$. The solid red curve illustrates distribution where the additional heat generated by the burning of organic material has increased temperatures of the penetration structures above the $85^{\circ} \mathrm{C}$ limit. The red hatch marks indicates the area where temperatures may exceed the ignition temperatures of building materials.

much lower, below $200^{\circ} \mathrm{C}$ [14, 22-24]. Wood fibre insulation begins to smoulder at temperatures between $225^{\circ} \mathrm{C}$ and $290^{\circ} \mathrm{C}[25,26]$. Conservative generic values of the critical ignition temperatures for rigid polyisocyanurate foam (PIR) and rigid phenolic foam (PF) are approximately $300^{\circ} \mathrm{C}$ and $425^{\circ} \mathrm{C}$, respectively [21, 27]. Expanded polystyrene (EPS) melts prior to pyrolysis at around $240^{\circ} \mathrm{C}$ [21].

Mineral wool insulation products are often used as chimney penetration insulation due to their good fire performance. In the field of fire safety, the most essential characteristics and testing procedures for building products are defined by the harmonized Euroclass system. The system includes a classification system that is based on the reaction-to-fire performance and defines the test methods according to which products shall be categorised. Mineral wool may be included in the highest category Euroclass A1 (non-combustible). The classification and the reactionto-fire properties are determined either by testing or by the CWFT (classification without further testing) regulation by the European Commission. The EN 13501-1 classification standard [16] sets threshold values for Euroclass A1 products. Noncombustibility is determined in accordance with EN ISO 1182 [28] and calorific value in accordance with EN ISO 1716 [29]. In addition, the method specified in EN 13823 [30] is also used. Commission Decision 96/603/EC [31] contains a list of products that may be included in Euroclass A1 without testing. Mineral wool is one of the materials. None of these materials are allowed to contain more than $1.0 \%$ by weight or volume (whichever is the lower amount) of homogeneously distributed organic material. For mineral wool, this is demonstrated by tests carried out in accordance with the method given in EN 13820 [32]. The percentage of organic material in the insulation is called an LOI (Loss On Ignition) value and it states the content of the mass of organic material in relation to the original mass of the sample. 
A new testing method for analysing and assessing continuous glowing combustion testing was published in May 2016 and is introduced in EN 16733 [33]. The method, which was developed by the Institut für Brandtechnologie GmbH [34], is based on the method specified in EN 13823 [26]. In the research carried out by the Institut für Brandtechnologie $\mathrm{GmbH}$, three different mineral wool products were tested. The mineral wool binder contents were measured at $3.2 \%, 4.6 \%$ and $3.7 \%$ by weight (LOI values). No continuous glowing combustion was detected in the product with the lowest LOI value. This was explained by the low binder content. With the two other mineral wools, glowing combustion was reported. The study report did not include more specific product information or material characteristics.

Previous research have demonstrated that the smouldering combustion of mineral wool insulation products can increase the temperatures of chimney penetration construction during heater operation [6, 7]. However, the research did not consider how sensitive the temperature rise is to the amount of organic content or how high the temperature can rise due to smouldering combustion. For analysing the effects of organic content on the fire safety of chimney penetration construction more information was required on how much the organic content can increase the temperatures and how long is the time the structures are exposed to this additional heat. The above standardized methods are predominantly testing the performance of a building product exposed to an open flame and, therefore, do not correspond to continuous heating conditions. Further research was, therefore, required to determine whether or not the additional heat generated by the burning of organic material should be taken into account when designing chimney penetrations and to develop a robust method for controlling the maximum temperatures in the chimney penetration structures.

In order to answer the above questions an experimental study [8] was carried out at Tampere University (formerly Tampere University of Technology). This paper introduces the test program and the main results of the study and, then analyses and discusses whether or not the additional heat generated by the burning of organic material should be taken into account when designing chimney penetrations, and whether the amount of organic material in penetration insulation should be limited in order to impact heat release and reduce fire hazards.

\section{Research Method}

The aim of the experimental research was to determine how much additional heat typical mineral wool insulation products used as chimney penetration insulation are generating when exposed to high temperatures. The research consisted of two steps. In the first step, the amount of organic material in each mineral wool test sample was determined by burning the samples in an electric furnace and by comparing the weighed masses of the samples prior and after the burning. In the second step, new samples from the same insulation products as used in step 1 were installed into a support structure placed on the furnace front opening. In these tests, the temperatures of the mineral wool samples were monitored from various 
points of the samples and over a longer period of time. Each sample was exposed to same temperature twice and the additional heat generated by the burning of organic material was then measured as the difference between the temperatures during the two heat exposure. By combining the results of the two steps, it was then possible to interpret the relationship between the organic content and the maximum temperature rise in a mineral wool sample and further in a product. The method is presented in Fig. 4.

The details of the test program, equipment and methodology are described in the following subsections.

\subsection{Test Program}

The amount of organic material in the mineral wools affects the heat generation and, therefore, several mineral wool products with different amounts of organic material were included in the experimental test program. Three different manufacturers were included in the study and seven different products were tested. All of the tested products except one were primarily intended to serve as chimney penetration insulation. The other product was intended for steelwork fire protection. According to the Declaration of Performances by the manufacturers, all of the tested products were classified as Euroclass A1 (non-combustible).

This report does not contain the actual product names, but the samples have been given letter-number combinations. The letters $\mathrm{a}, \mathrm{b}$ and $\mathrm{c}$ refer to the three manufacturers. The subsequent numbers refer to a particular product from the manufacturer. The test included four products from manufacturer a. Product a2 was not meant for chimneys. Two products were from manufacturer $b$ and one product was from manufacturer c. The products were acquired from various hardware stores in Finland.

\subsection{Research Equipment}

An electric Ceramotherm furnace was used for the study. Its inner dimensions are $550 \mathrm{~mm} \times 700 \mathrm{~mm} \times 800 \mathrm{~mm}$, and the maximum temperature is $1340^{\circ} \mathrm{C}$ (Fig. 5).

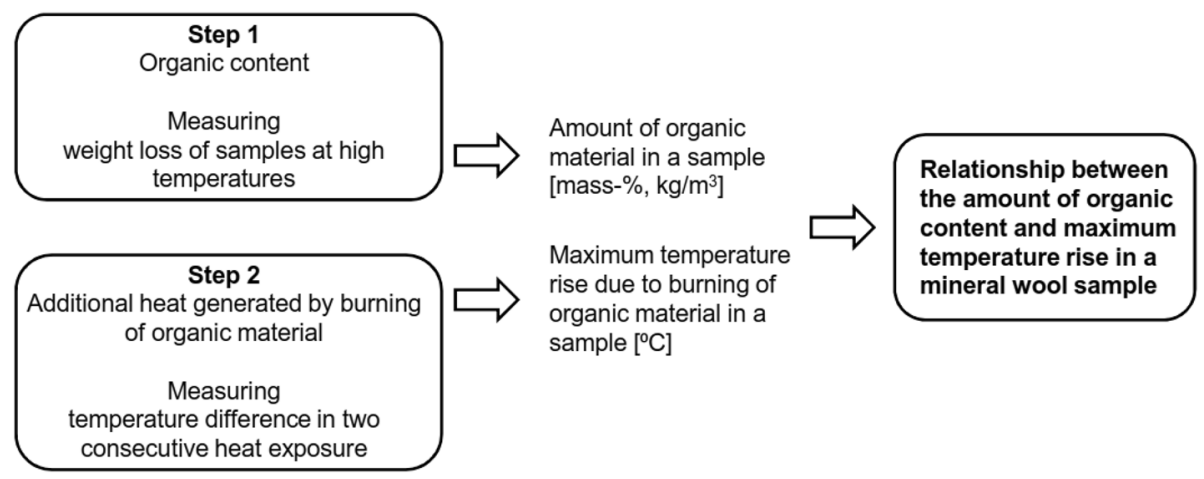

Figure 4. Steps of the experimental research. 
The furnace temperature was measured from the centre of the furnace using a type- $\mathrm{K}$ sheathed thermocouple. The furnace temperature was controlled with a computer program. Depending on the temperature measured, the computer turned the furnace resistors on and off. When determining the amount of organic material and heat release, $500^{\circ} \mathrm{C}$ was the highest temperature that was used.

\subsection{Organic Content}

The amount of dissipated organic material in a mineral wool test sample was determined by keeping the sample in a constant temperature furnace environment over $2 \mathrm{~h}$ and measuring the weight loss of the sample. The dissipation of organic material was measured at three different temperatures: $300^{\circ} \mathrm{C}, 400^{\circ} \mathrm{C}$ and $500^{\circ} \mathrm{C}$. The organic material in the mineral wool was burned during the process, with the mass of organic material dissipated at different temperatures determined as the difference between the weighed masses.

The material samples used in the tests were of disc shape with a diameter of $90 \mathrm{~mm}$ and thickness of $50 \mathrm{~mm}$. Three test samples were prepared from each insu-

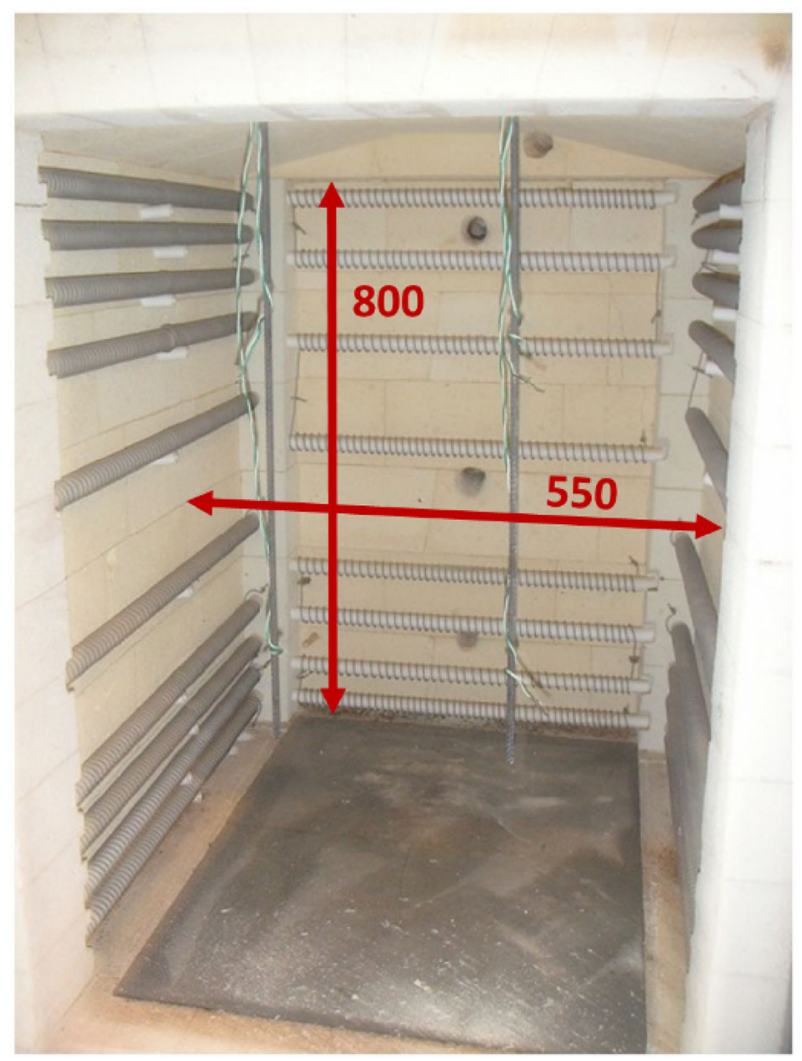

Figure 5. Electric Ceramotherm furnace with inside dimensions of $550 \mathrm{~mm} \times 700 \mathrm{~mm} \times 800 \mathrm{~mm}$. 
lation type. A hole saw was used to remove discs from mineral wool boards. The texture of insulation sample a3 was so soft that a hole saw could not be used. Instead, test samples of $100 \mathrm{~mm} \times 100 \mathrm{~mm} \times 50 \mathrm{~mm}$ were cut out of insulation material a3.

The test samples were weighed and then dried at a temperature of $105^{\circ} \mathrm{C}$. The dried samples were then weighed and set in the electric furnace (Fig. 6). The furnace was first heated to $300^{\circ} \mathrm{C}$ and kept at this temperature for $2 \mathrm{~h}$. Then the test samples were weighed. The heating was repeated, first to $400^{\circ} \mathrm{C}$ and then to $500^{\circ} \mathrm{C}$, with the same test samples weighed after both rounds of heating. The test differed from the test specified in standard EN 13820 [32] in that the test samples were heated to three different temperatures, whereas the standard test only uses $500^{\circ} \mathrm{C}$. In the standard test of [32], the test sample consists of at least eight smaller specimens from different parts of the insulation product. In this research, the number of specimen was limited to three and, therefore, larger specimens were used to cover local differences in the amount of organic material.

\subsection{Additional Heat Generated by the Burning of Organic Material}

The test arrangement and the preparation and instrumentation of the samples are based on an earlier study [7]. Three tests were carried out using the electric furnace, with each test consisting of four samples installed into support structure placed on the furnace front opening. During the first two tests, a furnace temperature of $500^{\circ} \mathrm{C}$ was maintained. During the third test, the temperature was $300^{\circ} \mathrm{C}$ in order to assess the amount of additional heat at a lower temperature. One test included two separate rounds of heating that were named the first and second heating. During the first heating, the organic material in the insulation burned and caused additional heat. During the second heating, the organic material had already burned and did not have an effect on the temperature variation in the insulation. Thus, the second heating is similar to a situation in which there is no organic material in the insulation. The additional heat generated by the burning

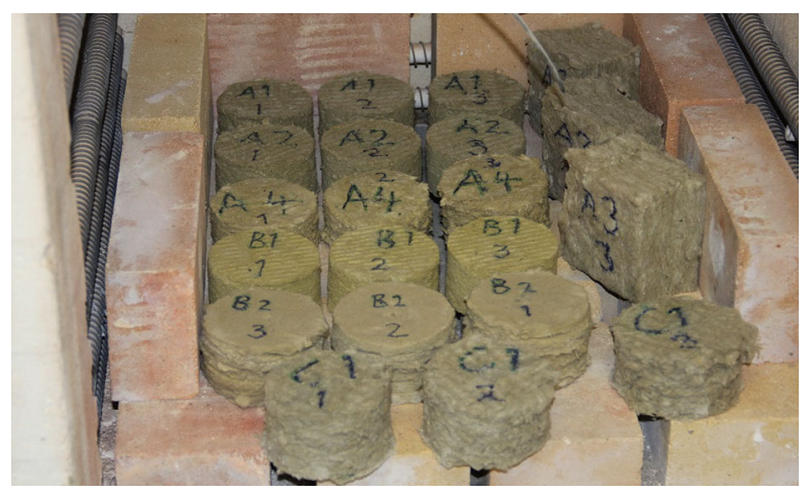

Figure 6. Test samples with a diameter of $90 \mathrm{~mm}$ and thickness of $50 \mathrm{~mm}$ set in the electric furnace to determine the amount of organic material. 
of organic material was then determined as the difference between the temperatures measured during the first and second heating.

The test samples were $200 \mathrm{~mm}$ square and $100 \mathrm{~mm}$ thick. The earlier study [7] concluded that a $100 \mathrm{~mm}$ thick test sample represents the maximum heat release generated by the burning of organic material in the test arrangement used. The selected sample thickness of $100 \mathrm{~mm}$ is also close to the thickness of typical chimney penetration insulation. The test samples were made of two approximately 50mm-thick mineral wool boards placed together back to back. One exception was test sample b2, which was made from ten 10-mm-thick mineral wool boards because that particular mineral wool product was only available with that thickness. The test samples were covered with aluminium foil, except for the side facing away from the furnace, to reduce the airflow inside of them. A foil-covered test sample is depicted in Fig. 7.

The temperature of the test samples was measured from the surface facing the furnace between the aluminium foil and the mineral wool, as well as from various points at $10 \mathrm{~mm}$ intervals through the cross-section all the way to the side facing away from the furnace. The structure of the test sample and the temperature measurement points are illustrated in Fig. 8. The surrounding room temperature, $\mathrm{T}_{\mathrm{amb}}$, was measured from a distance of two meters from the surface facing away from the furnace.

The test samples were installed into $100 \mathrm{~mm}$ thick support structure placed on the furnace front opening. The support structure was made of two $50-\mathrm{mm}$-thick mineral wool boards tied together using threaded rods and nuts, as shown in Fig. 9. Four square-shaped holes were cut into the boards into which the test samples were placed. The side dimensions of the holes and test samples were $200 \mathrm{~mm}$.

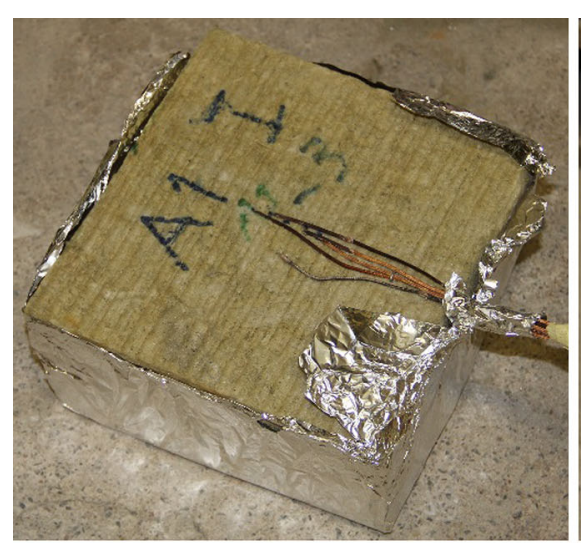

a

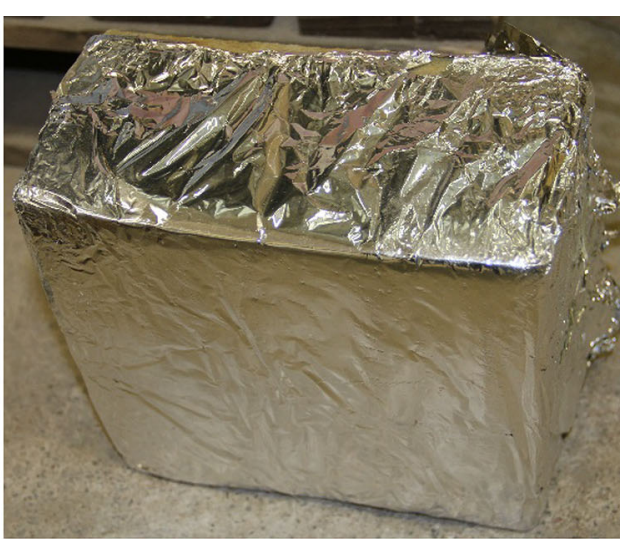

b

Figure 7. Test sample, $200 \mathrm{~mm}$ square and $100 \mathrm{~mm}$ thick, ready for the test pictured a from the side facing away from the furnace and $b$ from the side facing the furnace. 


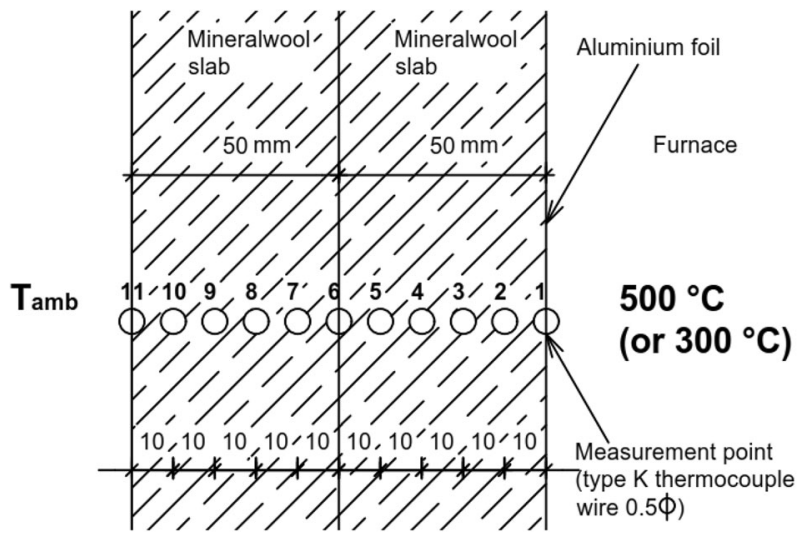

Figure 8. The cross-section of the $100 \mathrm{~mm}$ thick test sample used in the furnace tests and the measurement points.

Two tests were carried out at a furnace temperature of $500^{\circ} \mathrm{C}$ and one test at $300^{\circ} \mathrm{C}$. One test included two separate rounds of heating. At the start of the first heating, the furnace temperature was raised from room temperature to a target

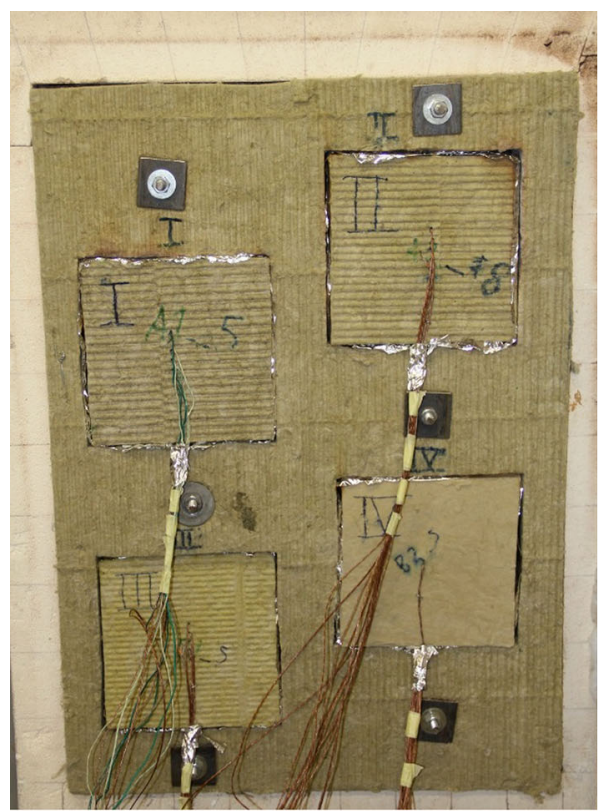

a

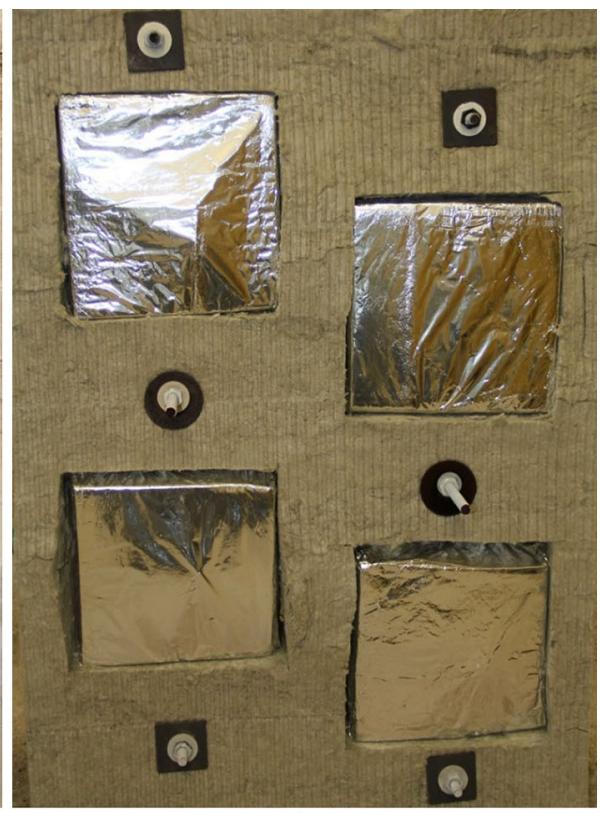

b

Figure 9. Test samples, $200 \mathrm{~mm}$ square, installed into the holes in the support structure from a the side facing away from the furnace and $b$ from the side facing the furnace. Pictures were taken after the test. 
temperature of $500^{\circ} \mathrm{C}$. During the heating of the furnace, 50 -mm-thick mineral wool slabs were used to cover the holes reserved for the test samples. After the furnace temperature had plateaued at $500^{\circ} \mathrm{C}$, the hole covers were removed, one by one, and replaced with the test samples. The test was then continued at $500^{\circ} \mathrm{C}$ until the temperatures measured from the samples did not change anymore, after which point the furnace was turned off. During the second heating, the test samples from the first heating were tested again in a manner similar to the first heating. The third test including four samples was carried out in a similar fashion, but the furnace temperature was set to $300^{\circ} \mathrm{C}$.

In this study, the additional heat generated by the burning of organic material was determined as the difference between the highest temperatures measured during the first and second heating. The highest temperatures were determined based on the measured temperature development at different points of the test sample cross-sections. The highest temperatures of the first heating (T1) were determined as the maximum value of the temperature peak whereas during the second heating, temperatures approached the maximum values (T2) at the end of the test. Temperature difference was then calculated as the difference between temperatures $\mathrm{T} 1$ and T2. The approach is demonstrated for test sample b1 in Fig. 12a.

\subsection{Measurement Uncertainty}

In the tests determining the content of organic material, the main source of uncertainty related to the measurement method is the accuracy of determining the dimensions of the test samples. The softest mineral wools are easily compressed, which made measurement more difficult. A hole saw was used to ensure maximum accuracy for the size of the test samples. For mineral wool a3, a hole saw could not be used, which increased the uncertainty regarding the measurements. Test samples for mineral wool a4 were cut from a cylinder-shaped pipe section, thus increasing the dispersion of the test sample thicknesses.

In the tests determining the heat generated by the burning of organic material, the temperature measured from a test sample is largely dependent on the distance of the measuring point to the heated surface. Even a small deviation in the measurement point location can have a significant impact on the temperature measured. With soft wool insulation in particular, it is difficult to determine the accuracy of the installation. This inaccuracy does not, however, affect the calculation of the temperature rise because the first and second heating are carried out with the same test samples and the measuring points remain the same. The deviations in measuring point locations do have an effect on the estimated shape of temperature distribution, but the effect of the deviations on the results (i.e., the allowed amount of organic material) of this study can be assumed to be small.

One important source of uncertainty in the method presented above is that the amount of organic material (Step 1) and the temperature rise (Step 2) were measured from different test samples taken from the same mineral wool product. As the binder density can vary in an insulation product, it is possible that the organic content used in the two tests was slightly different. 


\section{Test Results}

In this section, the results of the experimental test program described in Sect. 2 are introduced. The organic content of different mineral wool samples and the measured temperature development in the samples are reported in sub-clauses 3.1 and 3.2, respectively. Based on the results, the relationship between the organic content and the corresponding temperature rise can be determined. The results also demonstrate the magnitude and duration of the temperature peak.

\subsection{Organic Content}

Table 1 shows the amounts of organic material in the test samples used in the furnace tests. The contents of organic material varied between $1.3 \%$ and $4.5 \%$ by weight, but these contents do not tell us anything about the crucial factor for heat release (i.e., the amount of organic material burned). A better indicator is the amount of organic material by volume. The lowest amount of organic material by volume was in insulation product a3, approximately $1.0 \mathrm{~kg} / \mathrm{m}^{3}$. The largest amount of organic material by volume was measured in insulation b1, over $5.0 \mathrm{~kg} / \mathrm{m}^{3}$. Overall, it can be stated that the denser mineral wools contained more organic material.

The dissipation of organic material was measured at three different temperatures: $300^{\circ} \mathrm{C}, 400^{\circ} \mathrm{C}$ and $500^{\circ} \mathrm{C}$. A clear mass loss was observed at temperature of $300^{\circ} \mathrm{C}$. The most significant portion of organic material had dissipated at $400^{\circ} \mathrm{C}$, but a small amount of it was still burning at $500^{\circ} \mathrm{C}$. Figure 10 depicts the amount of dissipated organic material by volume in different test samples and at different temperatures.

The results indicated some dispersion for the amount of organic material in mineral wool. Table 1 shows that the consistency and mass of test sample b1:2 differed significantly from the other two test samples from the same product. The deviation was considered so large that test sample b1:2 was excluded from the heat release study that was reported in Sect. 3.2.

\subsection{Additional Heat Generated by the Burning of Organic Material}

Temperature graphs for the first heating of test samples b1 and $\mathrm{cl}$ are illustrated in Fig. 11. Sample b1 represents a product with high organic content (over $5 \mathrm{~kg} /$ $\mathrm{m}^{3}$ ) and $\mathrm{c} 1$ signifies a product with low organic content (approx. $2 \mathrm{~kg} / \mathrm{m}^{3}$ ). The graphs represent temperatures on the test sample cross-sections at $10 \mathrm{~mm}$ intervals, during the first heating and with the furnace temperature at $500^{\circ} \mathrm{C}$. Additional heat release that stabilizes over the course of $180 \mathrm{~min}$ was clearly noticeable. The temperature rise is clearly lower and the organic material burns to completion faster when the concentration is low.

With this test arrangement, the largest temperature rise generated by the burning of organic material was measured at approximately the centre of the test sample. When moving towards the surface facing away from the furnace, the additional heat was significantly reduced, as there was less burning of the organic material and less heat release due to a lower temperature. No burning of organic material occurred 
Table 1

Results for the amount of organic material in mineral wool. The maximum standard deviation calculated for the organic content of an insulation product was $0.17 \mathrm{~kg} / \mathrm{m}^{3}$ (a 4 )

\begin{tabular}{|c|c|c|c|c|c|c|c|c|c|}
\hline $\begin{array}{l}\text { Test } \\
\text { sample }\end{array}$ & $\begin{array}{c}\text { Volume } \\
\left(\mathrm{m}^{3}\right)\end{array}$ & $\begin{array}{l}\text { Mass } \\
(\mathrm{g})\end{array}$ & $\begin{array}{l}\text { Dry } \\
\text { mass } \\
(\mathrm{g})\end{array}$ & $\begin{array}{l}\text { Density } \\
\left(\mathrm{kg} / \mathrm{m}^{3}\right)\end{array}$ & $\begin{array}{c}\text { Mass } \\
(\mathrm{g}) \\
\left(300^{\circ} \mathrm{C}\right)\end{array}$ & $\begin{array}{c}\text { Mass } \\
(\mathrm{g}) \\
\left(400^{\circ} \mathrm{C}\right)\end{array}$ & $\begin{array}{c}\text { Mass } \\
(\mathrm{g}) \\
\left(500^{\circ} \mathrm{C}\right)\end{array}$ & $\begin{array}{c}\text { LOI } \\
\text { value } \\
\text { (mass\%) }\end{array}$ & $\begin{array}{l}\text { Amount of } \\
\text { organic con- } \\
\text { tent }\left(\mathrm{kg} / \mathrm{m}^{3}\right)\end{array}$ \\
\hline \multicolumn{10}{|l|}{ a1 } \\
\hline 1 & 0.00031 & 42.81 & 42.71 & 140 & 42.37 & 41.75 & 41.68 & $2.41 \%$ & 3.37 \\
\hline 2 & 0.00031 & 41.88 & 41.74 & 137 & 41.41 & 40.84 & 40.73 & $2.42 \%$ & 3.31 \\
\hline 3 & 0.00030 & 43.64 & 43.54 & 146 & 43.16 & 42.57 & 42.47 & $2.46 \%$ & 3.58 \\
\hline \multicolumn{10}{|l|}{$\mathrm{a} 2$} \\
\hline 1 & 0.00031 & 55.69 & 55.56 & 182 & 55.06 & 54.17 & 54.08 & $2.66 \%$ & 4.85 \\
\hline 2 & 0.00031 & 56.11 & 55.99 & 183 & 55.5 & 54.62 & 54.51 & $2.64 \%$ & 4.85 \\
\hline 3 & 0.00030 & 55.03 & 54.92 & 184 & 54.42 & 53.58 & 53.47 & $2.64 \%$ & 4.85 \\
\hline \multicolumn{10}{|c|}{ - } \\
\hline 1 & 0.00057 & 39.11 & 39 & 68 & 38.69 & 38.43 & 38.43 & $1.46 \%$ & 1.00 \\
\hline 2 & 0.00060 & 38.52 & 38.42 & 64 & 38.1 & 37.88 & 37.87 & $1.43 \%$ & 0.92 \\
\hline 3 & 0.00062 & 41.5 & 41.43 & 67 & 41.13 & 40.92 & 40.88 & $1.33 \%$ & 0.89 \\
\hline \multicolumn{10}{|l|}{ a4 } \\
\hline 1 & 0.00026 & 22.26 & 22.22 & 85 & 22 & 21.69 & 21.63 & $2.66 \%$ & 2.26 \\
\hline 2 & 0.00026 & 21.59 & 21.53 & 83 & 21.35 & 21.08 & 21.02 & $2.37 \%$ & 1.96 \\
\hline 3 & 0.00033 & 25.86 & 25.78 & 78 & 25.55 & 25.18 & 25.12 & $2.56 \%$ & 2.00 \\
\hline \multicolumn{10}{|l|}{ b1 } \\
\hline 1 & 0.00031 & 50.97 & 50.82 & 163 & 50.29 & 49.35 & 49.18 & $3.23 \%$ & 5.26 \\
\hline 2 & 0.00031 & 40.85 & 40.71 & 133 & 40.29 & 39.46 & 39.32 & $3.41 \%$ & $4.55^{\mathrm{a}}$ \\
\hline 3 & 0.00031 & 47.87 & 47.75 & 153 & 47.24 & 46.28 & 46.06 & $3.54 \%$ & 5.42 \\
\hline \multicolumn{10}{|l|}{ b2 } \\
\hline 1 & 0.00032 & 29.95 & 29.77 & 94 & 29.24 & 28.57 & 28.43 & $4.50 \%$ & 4.21 \\
\hline 2 & 0.00032 & 32.69 & 32.52 & 102 & 32 & 31.29 & 31.12 & $4.31 \%$ & 4.40 \\
\hline 3 & 0.00032 & 28.78 & 28.62 & 90 & 28.1 & 27.44 & 27.31 & $4.58 \%$ & 4.12 \\
\hline \multicolumn{10}{|l|}{$\mathrm{cl}$} \\
\hline 1 & 0.00032 & 31.48 & 35.67 & 110 & 35.35 & 35.01 & 34.97 & $1.96 \%$ & 2.16 \\
\hline 2 & 0.00032 & 33.5 & 33.4 & 105 & 33.11 & 32.77 & 32.73 & $2.01 \%$ & 2.11 \\
\hline 3 & 0.00032 & 35.8 & 31.4 & 99 & 31.14 & 30.85 & 30.8 & $1.91 \%$ & 1.89 \\
\hline
\end{tabular}

${ }^{a}$ Result differs significantly from the other values and was thus excluded from the analysis

near the outer surface of the test sample, and the additional heat was able to be transferred from the centre to the surrounding area through the surface. Also convection affects the temperatures on the side facing away from the furnace. This outcome differs from a chimney penetration, as the penetration insulation faces the thermal insulation within the roof. This observation means the additional heat is not able to cool down in the same way as during the furnace test.

Figure 12 illustrates the temperature graphs for the first and second heating for the test samples b1 and cl measured at a distance of $50 \mathrm{~mm}$ from the surface facing the furnace. The heat release generated by the burning of organic material was evident during the first heating, but the second heating of the same test samples did not create any heat release. When comparing the results from the first and 
6

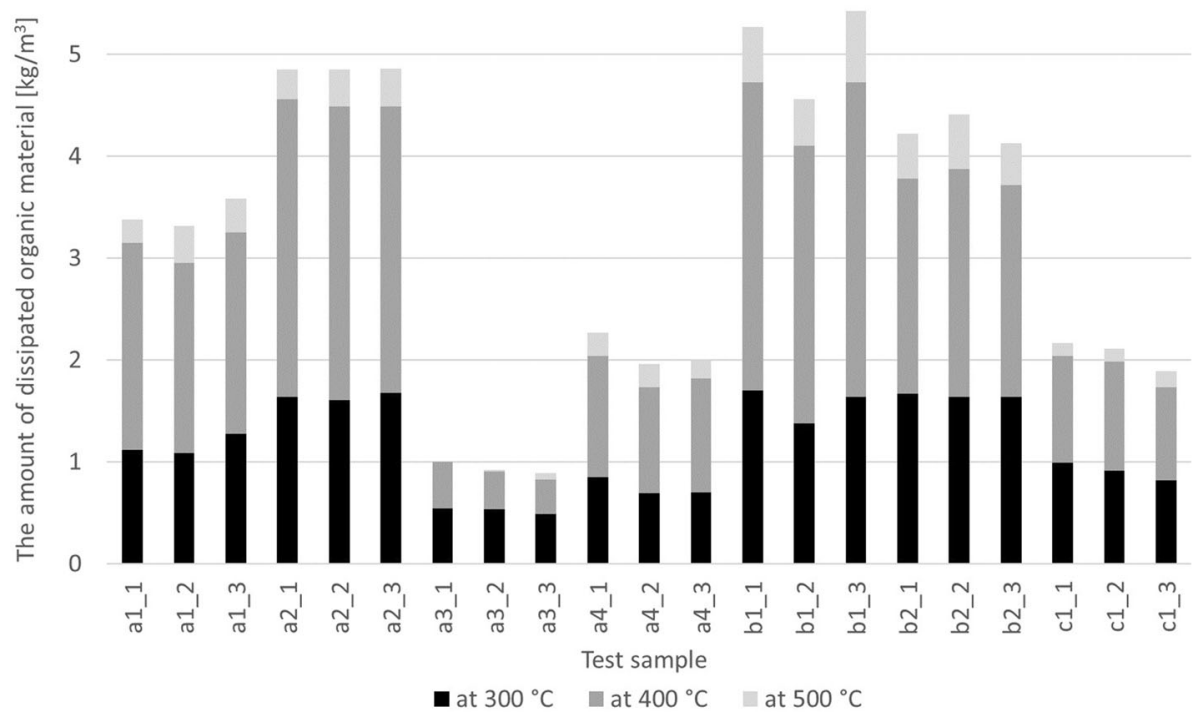

Figure 10. The amount of dissipated organic material at various temperatures.

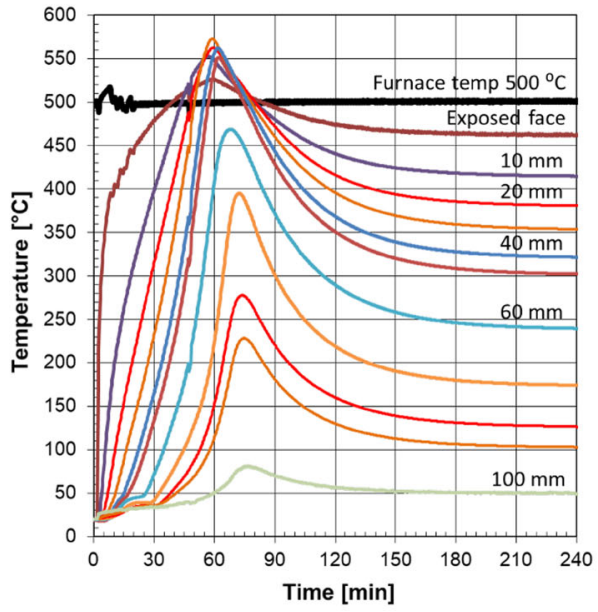

a

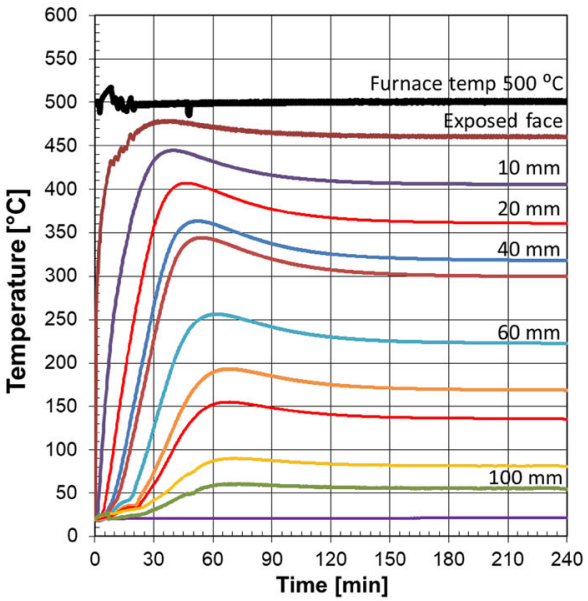

b

Figure 11. Temperatures on the test sample cross-section at $10 \mathrm{~mm}$ intervals, during the first heating and with the furnace temperature at $500^{\circ} \mathrm{C}$ (solid thick line): a test sample b1; b test sample c1 . 
second heating, the temperature rise generated by the burning of organic material is visible. For sample b1, the maximum difference in temperature was measured at $60 \mathrm{~min}$ and it was $300^{\circ} \mathrm{C}$. The duration of this peak was approximately $150 \mathrm{~min}$ $(2.5 \mathrm{~h})$. For sample $\mathrm{c} 1$, the maximum temperature difference was $100^{\circ} \mathrm{C}$ at $45 \mathrm{~min}$ and the duration was $120 \mathrm{~min}$.

Based on the measured temperature data, the organic material can be presumed to have been burned during the first heating. Tables 2 and 3 present the highest temperatures measured during the first (T1) and second (T2) heating, as well as the temperature increase (T2-T1) at various points within the mineral wool crosssections. The definitions of the highest temperatures are given in sub-Sect. 2.4. Table 4 presents equivalent measurement results for the third test with the furnace temperature maintained at $300^{\circ} \mathrm{C}$. The results demonstrate that none of the test samples exhibited significant heat release during this third test. For test sample b1, higher temperatures were measured during the second heating and it can be assumed that no burning of organic material occurred.

Figures 13 and 14 illustrate the temperature rise measured from different points of the mineral wool cross-section at $500^{\circ} \mathrm{C}$. The temperature rise refers to the difference between the highest temperatures measured during the first (T1) and second (T2) heating.

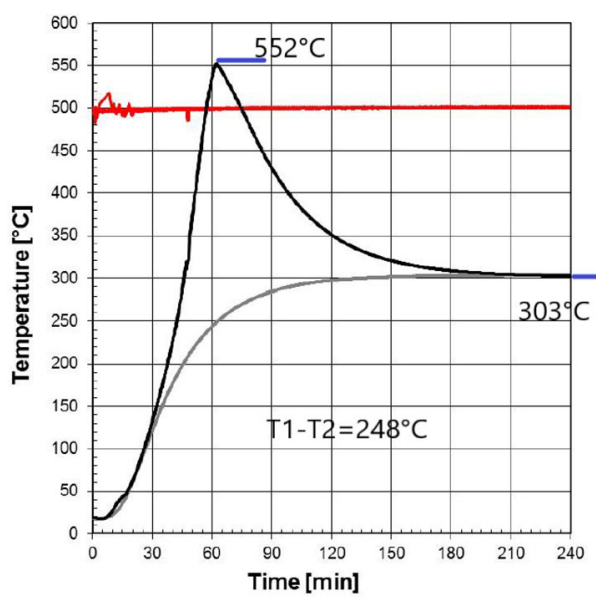

a

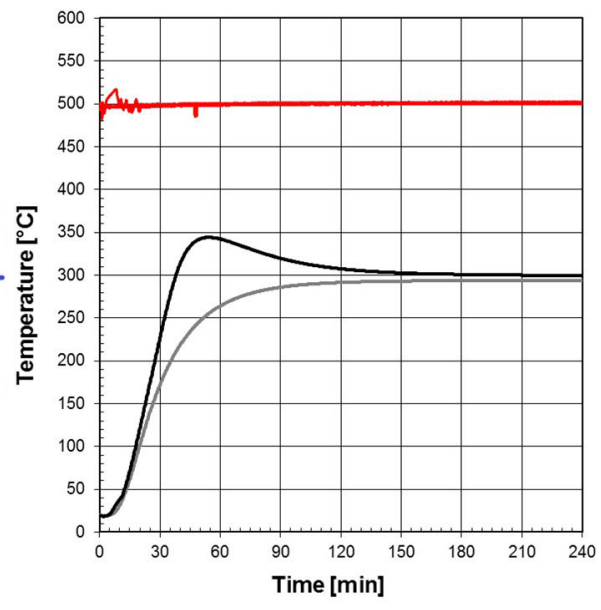

b

Figure 12. Temperafures at the centre of the test sample crosssection during the first (black curve) and second (grey curve) heating with the furnace temperature at $500^{\circ} \mathrm{C}$ : a test sample $\mathrm{b} 1$; b test sample 1 . 


\section{Table 2}

Highest temperatures at different points of the test sample crosssections during the first (T1) and second (T2) heating of test series 1 with the furnace temperature at $500^{\circ} \mathrm{C}$. The distance is measured from the surface facing the furnace

\begin{tabular}{|c|c|c|c|c|c|c|c|c|c|c|c|c|}
\hline \multirow{2}{*}{$\begin{array}{l}\text { Test } 1 \\
\text { Dist. }\end{array}$} & \multicolumn{3}{|c|}{ a1 } & \multicolumn{3}{|c|}{$\mathrm{a} 4$} & \multicolumn{3}{|c|}{ b2 } & \multicolumn{3}{|c|}{$\mathrm{cl}$} \\
\hline & $\mathrm{T} 1$ & $\mathrm{~T} 2$ & $\mathrm{~T} 1-\mathrm{T} 2$ & $\mathrm{~T} 1$ & $\mathrm{~T} 2$ & $\mathrm{~T} 1-\mathrm{T} 2$ & $\mathrm{~T} 1$ & $\mathrm{~T} 2$ & $\mathrm{~T} 1-\mathrm{T} 2$ & $\mathrm{~T} 1$ & $\mathrm{~T} 2$ & $\mathrm{~T} 1-\mathrm{T} 2$ \\
\hline $0 \mathrm{~mm}$ & 491 & 457 & 34 & 484 & 464 & 20 & 493 & 456 & 37 & 470 & 455 & 14 \\
\hline $10 \mathrm{~mm}$ & 482 & 392 & 90 & 0 & 0 & 0 & 529 & 413 & 116 & 419 & 385 & 35 \\
\hline $20 \mathrm{~mm}$ & 465 & 375 & 90 & 447 & 400 & 48 & 545 & 388 & 157 & 400 & 366 & 34 \\
\hline $30 \mathrm{~mm}$ & 460 & 352 & 108 & 437 & 379 & 58 & 552 & 350 & 203 & 359 & 321 & 38 \\
\hline $40 \mathrm{~mm}$ & 422 & 319 & 103 & 397 & 339 & 58 & 561 & 313 & 247 & 342 & 306 & 36 \\
\hline $50 \mathrm{~mm}$ & 404 & 301 & 102 & 388 & 330 & 57 & 566 & 282 & 284 & 317 & 281 & 37 \\
\hline $60 \mathrm{~mm}$ & 316 & 226 & 90 & 301 & 247 & 54 & 566 & 248 & 318 & 244 & 214 & 30 \\
\hline $70 \mathrm{~mm}$ & 265 & 194 & 71 & 234 & 195 & 39 & 518 & 207 & 311 & 180 & 159 & 21 \\
\hline $80 \mathrm{~mm}$ & 184 & 132 & 52 & 175 & 144 & 31 & 398 & 158 & 240 & 153 & 133 & 20 \\
\hline $90 \mathrm{~mm}$ & 88 & 74 & 14 & 101 & 84 & 18 & 281 & 102 & 179 & 98 & 89 & 9 \\
\hline $100 \mathrm{~mm}$ & 50 & 62 & -12 & 71 & 67 & 4 & 99 & 53 & 46 & 61 & 60 & 1 \\
\hline
\end{tabular}

\section{Table 3}

Highest temperatures at different points of the test sample crosssections during the first (T1) and second (T2) heating of test series 2 with the furnace temperature at $500^{\circ} \mathrm{C}$. The distance is measured from the surface facing the furnace

\begin{tabular}{|c|c|c|c|c|c|c|c|c|c|c|c|c|}
\hline \multirow{2}{*}{$\begin{array}{l}\text { Test } 2 \\
\text { Dist. }\end{array}$} & \multicolumn{3}{|c|}{ a2 } & \multicolumn{3}{|c|}{ a3 } & \multicolumn{3}{|c|}{ b1 } & \multicolumn{3}{|c|}{ c1_2 } \\
\hline & $\mathrm{T} 1$ & $\mathrm{~T} 2$ & $\mathrm{~T} 1-\mathrm{T} 2$ & $\mathrm{~T} 1$ & $\mathrm{~T} 2$ & $\mathrm{~T} 1-\mathrm{T} 2$ & $\mathrm{~T} 1$ & $\mathrm{~T} 2$ & $\mathrm{~T} 1-\mathrm{T} 2$ & $\mathrm{~T} 1$ & $\mathrm{~T} 2$ & $\mathrm{~T} 1-\mathrm{T} 2$ \\
\hline $0 \mathrm{~mm}$ & 503 & 469 & 34 & 453 & 454 & -2 & 527 & 466 & 61 & 480 & 464 & 15 \\
\hline $10 \mathrm{~mm}$ & 524 & 418 & 106 & 387 & 376 & 11 & 553 & 412 & 141 & 445 & 405 & 39 \\
\hline $20 \mathrm{~mm}$ & 520 & 376 & 144 & 361 & 346 & 15 & 563 & 380 & 183 & 407 & 356 & 51 \\
\hline $30 \mathrm{~mm}$ & 527 & 353 & 174 & 350 & 335 & 14 & 573 & 354 & 219 & & 335 & \\
\hline $40 \mathrm{~mm}$ & 492 & 318 & 174 & 326 & 309 & 16 & 562 & 322 & 240 & 363 & 312 & 51 \\
\hline $50 \mathrm{~mm}$ & 475 & 302 & 173 & 312 & 295 & 17 & 552 & 303 & 248 & 344 & 294 & 50 \\
\hline $60 \mathrm{~mm}$ & 387 & 231 & 157 & 173 & 159 & 14 & 469 & 234 & 235 & 256 & 214 & 42 \\
\hline $70 \mathrm{~mm}$ & 299 & 174 & 125 & 169 & 149 & 20 & 395 & 172 & 223 & 193 & 158 & 35 \\
\hline $80 \mathrm{~mm}$ & 228 & 133 & 95 & 87 & 76 & 11 & 278 & 124 & 154 & 155 & 128 & 27 \\
\hline $90 \mathrm{~mm}$ & 125 & 78 & 47 & 84 & 72 & 11 & 228 & 101 & 127 & 90 & 71 & 19 \\
\hline $100 \mathrm{~mm}$ & 76 & 49 & 28 & 70 & 63 & 7 & 81 & 48 & 33 & 60 & 53 & 8 \\
\hline
\end{tabular}

\section{Discussion}

The test results reported in Sect. 3 show that the temperature rise generated by the burning of organic material may increase the temperatures of penetration structures up to the ignition threshold of these materials. It is, therefore, important that the maximum possible temperatures and the risk of ignition in the chim- 


\section{Table 4 \\ Highest temperatures at different points of the test sample cross- sections during the first (T1) and second (T2) heating of test series 3 with the furnace temperature at $300^{\circ} \mathrm{C}$. The distance is measured from the surface facing the furnace}

\begin{tabular}{|c|c|c|c|c|c|c|c|c|c|c|c|c|}
\hline \multirow{2}{*}{$\begin{array}{l}\text { Test } 3 \\
\text { Dist. }\end{array}$} & \multicolumn{3}{|c|}{ a1 } & \multicolumn{3}{|c|}{$\mathrm{a} 2$} & \multicolumn{3}{|c|}{$\mathrm{b} 1^{\mathrm{a}}$} & \multicolumn{3}{|c|}{ b2 } \\
\hline & $\mathrm{T} 1$ & $\mathrm{~T} 2$ & $\mathrm{~T} 1-\mathrm{T} 2$ & $\mathrm{~T} 1$ & $\mathrm{~T} 2$ & $\mathrm{~T} 1-\mathrm{T} 2$ & $\mathrm{~T} 1$ & $\mathrm{~T} 2$ & $\mathrm{~T} 1-\mathrm{T} 2$ & $\mathrm{~T} 1$ & $\mathrm{~T} 2$ & $\mathrm{~T} 1-\mathrm{T} 2$ \\
\hline $0 \mathrm{~mm}$ & 261 & 263 & -2 & 288 & 284 & 3 & 244 & 246 & -2 & 278 & 274 & 3 \\
\hline $10 \mathrm{~mm}$ & 252 & 245 & 7 & 257 & 246 & 10 & 186 & 193 & -7 & 249 & 243 & 6 \\
\hline $20 \mathrm{~mm}$ & 223 & 217 & 6 & 234 & 224 & 10 & 164 & 170 & -6 & 229 & 225 & 4 \\
\hline $30 \mathrm{~mm}$ & 209 & 202 & 7 & 218 & 209 & 9 & 147 & 154 & -7 & 203 & 198 & 5 \\
\hline $40 \mathrm{~mm}$ & 191 & 185 & 6 & 197 & 190 & 8 & 130 & 137 & -7 & 178 & 174 & 4 \\
\hline $50 \mathrm{~mm}$ & 177 & 171 & 6 & 186 & 179 & 7 & 120 & 127 & -7 & 161 & 156 & 4 \\
\hline $60 \mathrm{~mm}$ & 125 & 119 & 6 & 150 & 145 & 5 & 88 & 94 & -6 & 137 & 137 & 1 \\
\hline $70 \mathrm{~mm}$ & 104 & 101 & 3 & 112 & 108 & 4 & 67 & 72 & -5 & 115 & 115 & 0 \\
\hline $80 \mathrm{~mm}$ & 72 & 70 & 2 & 87 & 84 & 3 & 53 & 56 & -3 & 87 & 88 & -1 \\
\hline $90 \mathrm{~mm}$ & 56 & 55 & 1 & 60 & 57 & 3 & 38 & 38 & 0 & 59 & 59 & 0 \\
\hline $100 \mathrm{~mm}$ & 43 & 42 & 1 & 40 & 39 & 0 & 32 & 31 & 1 & 36 & 36 & 0 \\
\hline
\end{tabular}

\footnotetext{
${ }^{\text {a }}$ Temperatures for test sample b1 remained so low that no burning of organic material occurred. Higher temperatures were measured for the test sample during the second heating
}

ney penetration area can be estimated. In this section, the fire-safe temperature levels are first discussed. The actual floor temperatures are then estimated according to the test results of Sect. 3. Finally, the EN standards specifying the fire resistance properties of penetration insulation materials are reviewed in the light of fire-safe amount of organic material they contain.

Based on the experimental results reported in Sect. 3, combustion burning can raise the temperature levels in a chimney penetration insulation up to $300^{\circ} \mathrm{C}$, which means that it is possible that the ignition temperatures of the combustible roof construction materials at safe distance are exceeded. If $200-250^{\circ} \mathrm{C}$ is considered a critical temperature level for the combustible materials, then the additional heat generated by smouldering combustion should cause an increase in temperature lower than $115-165^{\circ} \mathrm{C}$.

The mineral wool insulation products included in this research contained very different amounts of organic material that varied between $1.0 \mathrm{~kg} / \mathrm{m}^{3}$ (sample a3) and $5.0 \mathrm{~kg} / \mathrm{m}^{3}$ (sample b1). The heat release at different levels of organic content can be visualised with a graph in which the $\mathrm{x}$-axis represents the amount of organic material $\left(\mathrm{kg} / \mathrm{m}^{3}\right)$ and the $\mathrm{y}$-axis represents the temperature rise in test samples at $500^{\circ} \mathrm{C}$ furnace temperature. The temperature rise of all the eight test samples are shown as blue points in Fig. 15. The results represent the temperatures measured at $50 \mathrm{~mm}$ from the surface facing the test furnace. For the amount of organic material, the average value of the three test samples is used (refer to Table 1). The temperature rise is calculated as the difference between the highest temperatures from the first (T1) and second (T2) heating. Figure 15 shows that the temperature rise is almost directly proportional to the amount of organic 


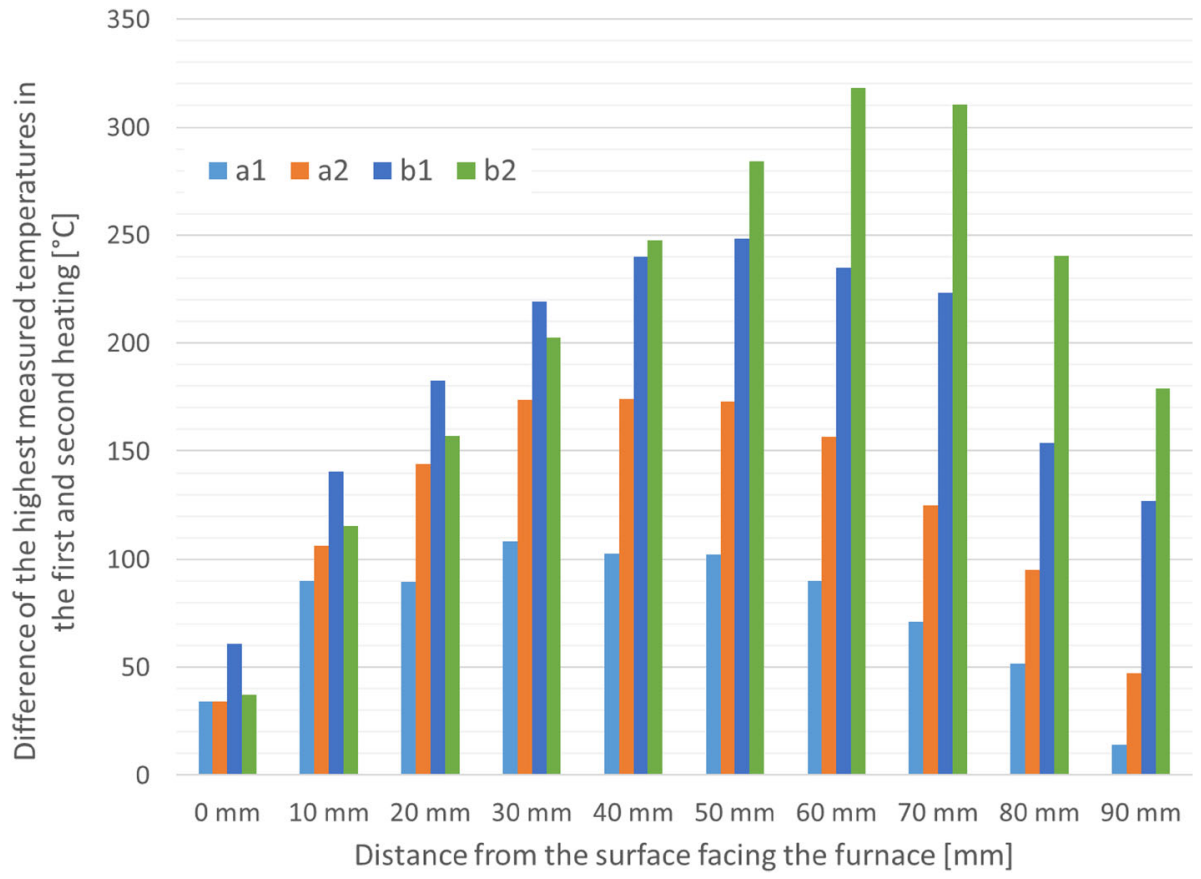

Figure 13. The differences in maximum temperature for the first and second heating at different points of the cross-section for test samples whose organic content was over $2.5 \mathrm{~kg} / \mathrm{m}^{3}$ (furnace temperature $\left.500^{\circ} \mathrm{C}\right)$.

material in the insulation $\left(\mathrm{kg} / \mathrm{m}^{3}\right)$. The dotted straight line in the figure is the best fit to the data points. The largest deviation between the linear best fit and the tested values was in sample b2, which consisted of ten 10-mm-thick mineral wool layers. It is assumed that the temperature rise was higher because this sample had better oxygen supply than the samples consisting of two 50 -mm-thick layers. It can be seen from the figure that an organic content of approximately $3.0 \mathrm{~kg} / \mathrm{m}^{3}$ would generate temperature rise critical for the fire safety of a chimney penetration. In this study, four out of seven products had organic content that exceeded $3.0 \mathrm{~kg} / \mathrm{m}^{3}$.

When the lowest LOI value of the tests carried out by the Institut für Brandtechnologie GmbH [34] is compared to the LOI values of the products included in this study, it can be seen that only two of the products exceed this LOI value. It would appear, based on this comparison, that EN 16733 [33] does not provide a sufficient method to ensure a fire-safe level of organic material. However, further studies are required to verify this observation.

Based on the above analysis, it can be concluded that the current standards used for assessing and classifying insulation products do not sufficiently take into account the effects of the temperature rise generated by the burning of organic material in continuous heating conditions. Further research is required to achieve 


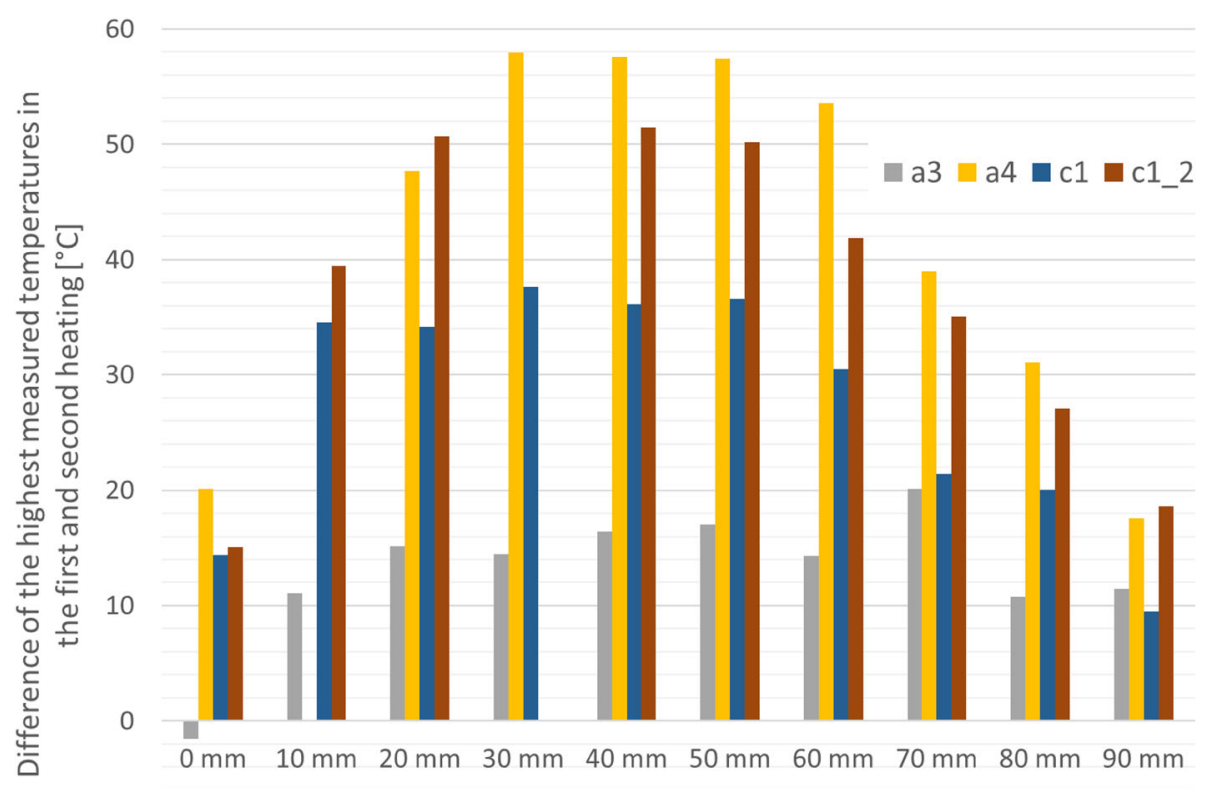

$-10$

\section{Distance from the surface facing the furnace [mm]}

Figure 14. The differences in maximum temperature for the first and second heating at different points of the cross-section for test samples whose organic content was under $2.5 \mathrm{~kg} / \mathrm{m}^{3}$ (furnace temperature $\left.500^{\circ} \mathrm{C}\right)$.

a robust method for controlling the maximum temperatures in the chimney penetration structures.

In the example used in this research it was assumed that the continuous working flue gas temperature is $600^{\circ} \mathrm{C}$, which corresponds to temperature class $\mathrm{T} 600$ of EN 1856-1 and, which is a very typical situation in Finland. For lower temperature classes the temperatures within the penetration construction are lower leading also to lower temperature rise due to burning of organic material. This can be seen from the results of test series 3 with the furnace temperature at $300^{\circ} \mathrm{C}$.

\section{Conclusion}

The paper presents experimental research on the smouldering of mineral wool insulation products specified for chimney penetrations and the heat release generated during the smouldering combustion. The following five conclusions can be drawn from the results of this study.

The smouldering combustion of the organic content in typical chimney penetration insulation products generates heat and can increase the temperature in chimney penetration materials by up to $250^{\circ} \mathrm{C}$ for a limited period of time. 


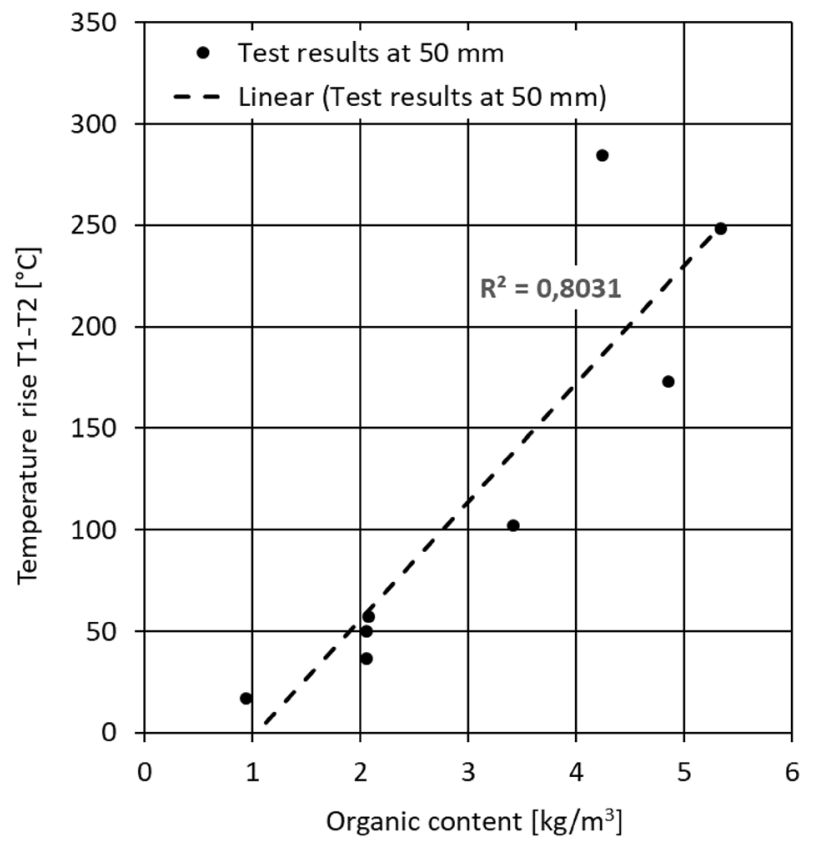

Figure 15. The effect of the amount of organic material on the temperature rise in the middle of the test samples at $500^{\circ} \mathrm{C}$ furnace temperature. The points represent determined values for products a 1 , a2, a3, a4, b1, b2 and c1.

Due to the additional heat release from smouldering, the ignition temperatures of combustible roof construction materials located adjacent to chimney penetration may be exceeded during normal fireplace operation. The experimental results show that the temperatures can be significantly higher than the fire-safe temperature levels given in product and test standards. Therefore, a potential fire hazard exists if the heat release is not limited to fire-safe levels.

The additional heat generated by the burning of organic material is proportional to the amount of organic material in mineral wool $\left(\mathrm{kg} / \mathrm{m}^{3}\right)$. A threshold value is required to limit the organic content in the penetration insulation materials to fire-safe level. Based on the results of this study, an organic content of approximately $3.0 \mathrm{~kg} / \mathrm{m}^{3}$ would generate a heat release that can lead to the ignition of combustible roof materials.

The European fire classification of materials does not set any requirements for controlling mineral wool smouldering and limiting the subsequent heat release in continuous heating conditions. Based on the results of this study, testing in accordance with EN ISO 1182 [28], EN ISO 1716 [29], EN 13820 [32] and EN 16733 [33] does not ensure the fire safety of chimney penetration structures. Further research is required to define a fire-safe threshold value and develop a reliable assessment method for organic content. Based on the results of this study, it is 
also more relevant to determine the amount of organic material by volume $(\mathrm{kg} /$ $\mathrm{m}^{3}$ ) than by the percentage by weight.

\section{Acknowledgements}

This work was supported by the Ministry of the Environment of Finland.

\section{Open Access}

This article is distributed under the terms of the Creative Commons Attribution 4.0 International License (http://creativecommons.org/licenses/by/4.0/), which permits unrestricted use, distribution, and reproduction in any medium, provided you give appropriate credit to the original author(s) and the source, provide a link to the Creative Commons license, and indicate if changes were made.

\section{References}

1. Ketola J, Kokki E (2018) Finnish rescue services' pocket statistics 2013-2017. Emergency Services College Publication. http://info.smedu.fi/kirjasto/Sarja_D/D3_2018.pdf. Accessed 30 Jan 2019

2. Buffo S, Dadone PN (2007) Studio statistico vigili del fuoco di Brescia sulle cause dell'incendito tetto (in Italian). Vigili del Fuco di Brescia, Brescia

3. Campbell R (2017) Home fires involving heating equipment. National Fire Protection Association NFPA, US. www.nfpa.org. Accessed 11 June 2018

4. Leppänen P, Inha T, Pentti M (2015) An experimental study on the effect of design flue gas temperature on the fire safety of chimneys. Fire Technol 51:847. https://doi.org/ 10.1007/s10694-014-0415-4

5. Leppänen P, Malaska M, Inha T, Pentti M (2017) Experimental study of fire safety of chimneys in real use and actual site conditions. J Build Eng 14:41-54. https://doi.org/ 10.1016/j.jobe.2017.09.014

6. Inha T, Leppänen P, Peltomäki M et al. (2011) Fire safety of light-weight metal chimneys. Research report no. PALO 1950/2011. Department of Civil Engineering, Tampere University of Technology, Finland. (In Finnish) 52 p. +25 p. app

7. Leppänen P, Neri M, Mäkinen J (2015) Heat release caused by the smouldering combustion of the binder of rockwool. J Struct Mech 48(1):68-82

8. Leppänen P, Malaska M (2016) The effects of smouldering combustion of mineral wool insulation with regard to fire safety of chimney penetrations. Research report no. PALO 2466/2016. Department of Civil Engineering, Tampere University of Technology, Finland. (In Finnish)

9. Neri M, Pilotelli M, Leppänen P, Pentti M, Bani S (2016) Experimental and computational study of the temperatures field around a chimney roof penetration. Fire Technol 52:1799-1823. https://doi.org/10.1007/s10694-015-0540-8

10. Neri M, Luscietti D, Fiorentino A, Pilotelli M (2015) Experimental analysis of chimneys in wooden roofs. Fire Technol 52:1939-1955. https://doi.org/10.1007/s10694-0150525-7 
11. Neri M, Luscietti D, Bani S, Fiorentino A, Pilotelli M (2015) Analysis of the temperatures measured in very thick and insulating roofs in the vicinity of a chimney. J Phys Conf Ser 655(1):012019. https://doi.org/10.1088/1742-6596/655/1/012019

12. Leppänen P, Neri M, Luscietti D, Bani S, Pentti M, Pilotelli M (2016) Comparison between European chimney test results and actual installations. J Fire Sci. https:// doi.org/10.1177/0734904116680222

13. EN 1856-1 (2009) Chimneys. Requirements for metal chimneys. Part 1: system chimney products. European Committee for Standardization (CEN), Brussels

14. Schaffer EL (1980) Smoldering initiation in cellulosics under prolunged heating. Fire Technol 16(1):22-28

15. EN 1859 + A1 (2013) Chimneys. Metal chimneys. Test methods. European Committee for Standardization (CEN), Brussels

16. EN 13501-1 + A1 (2009) Fire classification of construction products and building elements. Part 1: classification using data from reaction to fire tests. European Committee for Standardization (CEN), Brussels

17. Rogers FE, Ohlemiller TJ (1980) Smolder characteristics of flexible polyurethane foams. Fire Flamm 11:32-44

18. Palmer K (1957) Smoldering combustion in dusts and fibrous materials. Combust Flame 1:129

19. Ohlemiller TJ, Lucca DA (1983) An experimental comparison of forward and reverse smolder propagation in permeable fuel beds. Combust Flame 54:131

20. Rein G, Lautenberger C, Fernandez-Pello AC, Torero JL, Urba DL (2006) Application of genetic algorithms and thermogravimetry to determine the kinetics of polyurethane foam in smoldering combustion. Combust Flame 146:95-108

21. Hidalgo-Medina JP (2015) Performance-based methodology for the fire safe design in energy efficient buildings. Doctoral Thesis. The University of Edinburgh

22. Babrauskas V (2001) 'Pyrophoric Carbon' and long-term, low-temperature ignition of wood. https://www.doctorfire.com/low_temp_wood1.pdf. Accessed 12 June 2018

23. Kordina K, Meyer-Ottens C (1983) Holz Brandschutz Handbuch. Deutsche Gesellschaft für Holzforschung e.V. ISBN: 3-410-57041-1

24. Matson AF, Dufour RE, Breen JF (1959) Survey of available information on ignition of wood exposed to moderately elevated temperatures, Part II of "Performance of Type B Gas Vents for Gas-Fired Appliances" (Bull. of Research 51). Underwriters Press, Chicago

25. Jensen UE (2016) The development of smouldering combustion in combustible building insulation materials. Master Thesis. Norwegian University of Science and Technology

26. Steen-Hansen A, Mikalsen RF, Jensen UE (2018) Smouldering combustion in loose-fill wood fibre thermal insulation: an experimental study. Fire Technol 54:1585-1608. https://doi.org/10.1007/s10694-018-0757-4

27. Hidalgo JP, Welch S, Torero JL (2016) Experimental characterisation of the fire behaviour of thermal insulation materials for a performance-based design methodology. Fire Technol 00:00. https://doi.org/10.1007/s10694-016-0625-z

28. EN ISO 1182 (2010) Reaction to fire tests for products. Non-combustibility test. European Committee for Standardization (CEN), Brussels

29. EN ISO 1716 (2010) Reaction to fire tests for products. Determination of the gross heat of combustion (calorific value). European Committee for Standardization (CEN), Brussels

30. EN 13823 + A1 (2014) Reaction to fire tests for building products. Building products excluding floorings exposed to the thermal attack by a single burning item. European Committee for Standardization (CEN), Brussels 
31. Commission Decision 96/603/EC (1996) which has been changed by Commission Decisions 2000/605/EC (26 September 2000) and 2003/424/EC (6 June 2003)

32. EN 13820 (2003) Thermal insulating materials for building applications. Determination of organic content. European Committee for Standardization (CEN), Brussels

33. EN 16733 (2016) Reaction to fire tests for building products. Determination of a building product's propensity to undergo continuous smouldering. European Committee for Standardization (CEN), Brussels

34. Institut für Brandtechnologie $\mathrm{GmbH}$ (2004) Determination and assessment of the continuous glowing combustion behaviour of building products in the SBI test method. Final report. Project Nr. F 040101. BING TC 1831, 71 p

Publisher's Note Springer Nature remains neutral with regard to jurisdictional claims in published maps and institutional affiliations. 